\title{
CIVILIAN CONSERVATION CORPS WORK IN THE SOUTHWESTERN UNITED STATES
}

\author{
R. E. WiLson, B.Sc.F. \\ Cornell University, 1924, C.E.F. 1916-19. Cruising International Paper \\ Co. Ltd. and with U.S. Forest Service. Junior Forester Coconino National \\ Forest, Flagstaff, Arizona.
}

The program of the Civilian Conservation Corps in the Southwest, (Region 3 of the United States Forest Service comprising the states of Arizona and New Mexico) has three main objects. These are;

1. Road Construction.

2. Timber Stand Improvement.

3. Soil Erosion Control.

There are also minor types of work such as poison weed eradication, rodent control, range fence building, improvements in recreation grounds and other similar jobs. Fire fighting is, of course, vitally important and always takes precedence when the call comes.

Road construction is not the end and aim of forestry any more than other kinds of work but it shares a position of primary importance similar to fire prevention and control of which indeed it is an important part. Facilities for transportation are necessary for timber management and harvesting as well and for the convenience of the public seeking recreation and for other forest uses. So in a part of the country that is as comparatively newly developed as the Southwest, where only a few main trunk highways are paved and most of the roads are mere forest truck trails, road construction must play an important part in any plan of development. Thus in most of the C.C.C. camps a large proportion of the men are on road work detail. Apart from the number of men engaged in this work, its importance is emphasized by the expenditures on road machinery and equipment, i.e. caterpillar tractors, (cats) graders, bulldozers, air compressors, drills and dynamite. The largest number of supervisory jobs and men with ratings are in positions such as road engineers and foremen, "Cat" men, grader men, powder bosses and repair men.

The ultimate and most important goal of the C.C.C. work is in timber stand improvement (T.S.I.) Although the more general term forest stand improvement may be used, this would imply a broader field of work, including forest cover for watershed protection, wind control, recreation and timber growing. But for all of these, except the last, there is little need to improve on 
Old Mother Nature, as was recently demonstrated by the floods during the past summer in central New York where the heaviest damage was sustained in the man-made state parks and playgrounds. On the other hand, it is generally admitted by the forestry profession that our future timber crops will benefit by their improvement at the present time, for nature can be helped along in forestry just as she can in agriculture and in the medical and veterinary professions.

Briefly the T.S.I. work is mostly thinning and pruning. The terms forest culture and timber culture are sometimes used. In the southwest region weeding is not necessary where the yellow pine stands are of the purest and largest type. In the more elevated mountain regions where the mixed forests of Douglas fir, true fir and spruce are found, the T.S.I. work is confined to taking out the inferior species, namely the less valuable white and cork-bark fir. But at present these regions are comparatively inaccessible and are preserved for protection purposes.

Thinning is, at present, not entirely beyond the experimental stage. There are two questions involved, first the amount of opening up that a stand can take without too much drying of the site, for this region has the least rainfall and the greatest amount of sunshine of any part of the country: second whether the added growth after thinning is worth the labor expended. Tree growth is slower in the Southwest than in any part of the United States, except perhaps in the far north and as a result of this condition there is little appreciable increase due to release cutting. 'This has been, at any rate, the case in sample plots up to the present as shown by their measurement.

Clearing, if distinguished from thinning, consists of the cutting out of deformed, diseased, mechanically defective and low grade trees, wolf trees and such others as are competing in the crown cover. Intermediate and suppressed need often not be removed for they will succumb in due course from shade and snow damage, and root competition must be balanced against moisture content of the soil.

Experiments have been made this summer by the Director and his Staff at the Southwestern Forest Experiment Station in poisoning yellow pine instead of cutting it. There is always grave danger from "bugs" throughout the West and especially in the Southwest from the beetles of the Ipid family wherever there is fresh cutting or logging. Peeling the bark or burning must be resorted to and this accounts for the large labor cost. To avoid these the traptree method is used whereby felled trees are partially peeled, leaving the bark in strips three or four inches wide. The insects flying around in the stand, enter these bark strips and breed. However, before the new ones emerge the bark has been so dried out by the partial peeling that they are unable to escape. This does not always work perfectly and even the strip peeling is quite a cost 


\section{CIVILIAN CONSERVATION CORPS WORK}

item. Burning is too hazardous and girdling usually invites an insect infestation. Poisoning, however, has proved very successful in experiments. The labor required is far less than in felling. A crew of two or three men bore auger holes two to four inches deep slanting into the tree trunk and pour in a solution of 200 c.c. of lead acetate to each gallon of water. The trees begin die in two or three weeks which is a much shorter time than with girdling and no large holes are made in the crown cover of the stand as when a large wolf tree is cut out-, causing a sudden change such as drying cut, shock, or allowing of wind or snow damage. The fire hazard is a great deal less since no slash is left on the ground. Thus the danger of a ground fire becoming a crown one is lessened and with the dead trees falling one at a time, according to their height, over a period of years the fire is more readily confined to the ground. Due to lack of under brush and the nature of the stands crown fires are not common in the pure pine forests of the Southwest.

Felling of scattered dead snags as a fire hindrance is being discarded. Lightning probably hits more green trees than dry stubs or chicots. Recently the Bureau of Biological Survey has said that such dead trees should not be destroyed. This may sound unreasonable to the fire-fighter, but still the cost and work of chopping all these snags when doing the T.S.I. work in advance fire suppression (this work is not fire prevention) is not much less than the cost and work of watching and felling those found along the fire line in the event of a serious fire.

Now we come to the ultimate goal of Timber Stand Improvement, that is crop tree selection. This involves selecting the best trees at the optimum spacing to be pruned for the final crop. Thinning is mostly confined to the release of these trees. The trunk is then pruned progressively in the younger trees up to a height of a sixteen foot quality log for lumber. Long handled pruning saws are used.

When this work was begun at the inception of the C.C.C. in 1933, a complete over all thinning was made, and all the trees left were pruned. This perhaps had certain benefits in that it cleared the trees of limbs that might catch fire after the litter that is cut is rotted, in say, a year or two; it also ventilated the stand and in some measure prevented air stagnation and the entrance of western red-rot. It gave a parklike appearance to stands which in years to come might be used for recreation grounds rather than logging areas. However this is expensive work, so, in time, a modification of the crop-tree method was adopted which meant more trees and a larger timbered area

Only crop-trees are now pruned. In areas of full stocking all dead and suppressed limbs are trimmed off. Where trees grow in the open, heavy limbed and husky, half to two thirds the height of the tree is pruned of green limbs, depending on the crown size and taper of the trunk. The trees are ax pruned 
as high as possible. Of course this is faster work than saw pruning and an experienced woodsman with a sharp axe can cut yellow pine limbs without leaving a pitchpocket or torn scar.

At first this work was usually done by a gang of about twenty men under a forestry foreman, (graduate forester) who went ahead and blazed the trees to be felled, using a lighter blaze for trees to be pruned. Under the forester a "straw boss" was appointed to supervise the work. When it is possible to teach the men a better method is to show them the purpose of the work, what it is all about. In the average man this stimulates an interest in the work and such interest is the secret of success in handling subordinate labor. An alternative way is to divide the different kinds of work among the men according to their various abilities, giving each a small and distinct part in the whole. This allows the forester in charge to supervise the work more easily and gives him more time to find and experiment with more efficient methods.

How many crop trees are left? It is found that in the virgin yellow pine stands that the land will support forty trees to the acre. In tree space this allows the very good crown spread of twenty feet for mature trees. This is the final crop. However in areas where the trees vary in size from large sapling to large pole stands, more trees must be left to allow for future losses, from porcupine girdling, errors in marking and possible intermediate thinnings for products such as mine timbers, telephone poles and railroad ties. The Experiment Station has sample plots with varying number of crop trees from eighty to one hundred sixty per acre. This variation in number of crop trees per acre must depend on the size and age of the trees, for saplings can be spaced at ten feet while large poles must have at least twenty feet.

The T.S.I. work of the summer changes in winter to soil erosion control in the more southern areas of forest semi-desert and grazing range land. Errosion control is a far more serious problem in the southern states than in the north, probably due to the greater agricultural activity in these states. The amount of rainfall in the floods, Vermont in 1927 and New York in 1935, although serious did comparatively little damage over large areas due to forest and grass cover, whereas a similar rainfall in North Carolina or in Arizona would have been disasterous. In the old South or southeastern states the rivers all flow to the sea and for their whole length are continually carrying the red or brown silt with them; in the Southwest, however, there are a few rivers, such as the Rio Grande and the Colorado that have a flow of water for their whole length but much of it is diverted for irrigation in such reclamation projects as the Boulder Dam. But the small rivers and streams are dry-beds for most of the year and when there is a heavy rain fall it may cause the river channel to flow full but only until the dry-beds absorb the volume or until the water runs out on a flat and disappears. Almost every water course in the Southwest from the 
roadside arroyo to the Grand' Canyon follows this rule. (The erosion engineers speak of the "cutting channel" and the "filling channel."

A.t first the soil erosion work of the C.C.C. was chiefly concerned with the building of check dams in eroding streams and arroyos. Check dams, as the name implies, are built to slow up the run of water, to deposit deltas above the dams and to refill the gullies. In very deep arroyos successive heights of dam are built progressively on the initial dan to accomplish this. The check dams are built of the most easily and cheaply obtained materials; of logs in forest regions and of rocks and stones in the desert areas. Fence wire and tarred burlap were used to bind the dam and to hold the silt for sealing. These dams provided much relief work, but, like all engineering work in erosion control, dams, levees, ditches, they are temporary, filling up with silt unless revegetation such as sod or forest cover is finally obtained. The check dams were built across arroyos which had no solid rock foundation and no amount of keying in would prevent the water from getting around the ends and leaving the dam standing like an island, in midstream. During a steady rain the water soaks into the ground and may not cause the stream to flow at all and so the dams do not function but a quick heavy rain fills the channels and the check dams go "galley-west." Check dam building should go hand in hand with revegetation and range planting as well as other methods of erosion control: stream diversion, water retention, irrigation and the proper crop, forage and forest coverage-but so far funds and material are slow in coming.

Now a brief account of the other C.C.C. jobs. Range fences are a crying need for the proper administration of grazing to keep the cattle on their proper seasonal range and so prevent range depletion. More telephone lines have to be built and kept in order for better communication over forest areas, linking ranger districts, lookout towers and other key points in fire protective work. Poison weed eradication on the range has only been experimented with.

Attempts have been made by the C.C.C. gangs under the supervision of the Biological Survey Bureau, to exterminate with gun and poison the rangedamaging prairie dogs, mice, squirrels and tree-girdling "quill-pigs." The damage done by porcupines in some areas almost equals that done by the white pine weevil in the Northeast. In the Prescott National Forest, Arizona, the major forest project has been the attempted elimination of a recently discovered twig blight which has become a grave menace.

New headquarters buildings at ranger stations are being built and in forests used for habitation the permanent springs must be developed for stock watering and fire fighting supply. Recreational facilities in forests must also be improved due to their rapidly spreading popularity throughout the country. Recreational Engineers are developing more attractive camping sites with picnic fire places, stone tables, camping shelters and other conveniences. 
The C.C.C. work, in spite of certain drawbacks, has been successful. The writer felt that at the end of the last European war in 1918 something like it might have been created to occupy the regular army's spare time and to absorb demobilized men. The C.C.C. may now continue as a small permanent organization to take care of the unemployed youth in the cities. The efficiency of the work has been lessened, for, as a relief ineasure, the men have been without the disciplining effect of the hire and fire system, and the chief means of getting work done has been by habit, patience and instruction. In the large stationary camps of about two hundred men it has been found that much time has been lost in travelling to and from work and smaller camps of twenty-five to fifty men have been advocated.

The C.C.C. project has been subjected to much criticisms, often without suggestions to remedy it, but as one of President Roosevelt's pet brain children it has certainly spelled action and in the words of the late Theodore Roosevelt, "We are coming to recognize as never before the right to guard our future in the essential matter of natural resources."

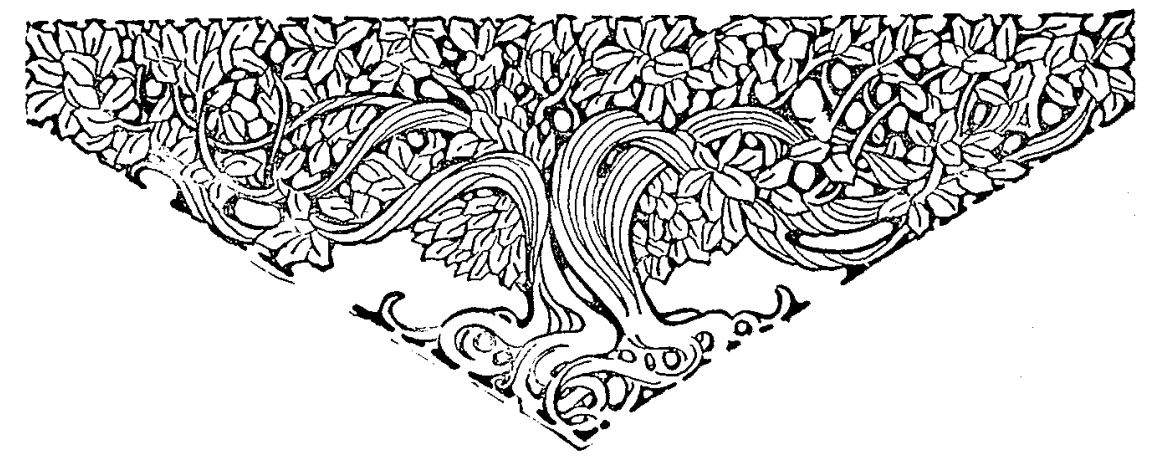

